\title{
A NEW READING OF THE HIGHGATE ARCHWAY SECTION.
}

\author{
BY W. J. LEWIS ABBOTT, F.G.S.
}

(Read 7th April, 1893.*)

\section{$T$}

HE succession and, indeed, the nature of the beds in the Highgate Archway Road has long formed the subject of a difference of opinion. Some observers, having seen the sands resting unconformably upon black London clay (as shown in the N. end of section II.), and noting various physiographical features of the surrounding country, have regarded them as Bagshots. $\dagger$ Others, having seen such sections as that exposed in the N.W. end of section I., where the fossiliferous clays pass insensibly into fossiliferous sands, gradually changing in colour from dark green to bright yellow, have disputed the claim of the sands to the term Bagshot, and have regarded them as "sands of the London Clay." Up till recently good sections were wanting, but in 1889 and $\mathrm{I} 890$ the whole of the fields on the N. side were laid out for building purposes, and a large number of sections and cross-sections exposed. It will be unnecessary to describe all these, or to refer to them in the order in which they were made, or to detail the apparent anomalies they presented when viewed in the light of former opinions.

It will be remembered that the Archway Road runs N.W. and S.E., and that it is an artificial cutting through a hill. As the beds dip at a greater angle than the road, it is evident that the hill coincides with an upheaval, and is not entirely due to denudation. The various sections exposed showed the hill to be the end of a dome dipping in the direction of the road, and also almost at right angles to it, so that the succession and relation of the beds can be best shown by two sections taken in these directions. Section $I$. is compiled from various continuous exposures that were made parallel to the road for a quarter of a mile. In this distance there is a fall in the surface from $33^{2}$ feet O.D. to 226 feet O.D. The foundations for the houses at the N.W. end of the section revealed the lowest bed exposed, No. I. It is an unctuous clay, containing a band of Rostellaria lucida and three or four other species. This bed quickly passes into one which is a dark green highly fossiliferous glauconitic sand (No. 2), similar to a bed met with in Finchley Road sewer, where I obtained from it some fifty species, nearly all of which were also found at Highgate. I have further seen it in various sections round Hamp-

* [The title has since been modified.-ED.]

† "Geology of London," vol. i, p. 269 .

OCTOBER, I 893 .] 
stead, and Prof. Prestwich considers it to be the correlative of the bed at Brentwood, described by him in his Westleton paper.* It was this bed that yielded nearly all the fossils in the appended list. At this point it is about ten feet in thickness; it then becomes more clayey and of a light brown hue, thus passing into bed No. 3. This latter is never a decided clay, and at a distance of ten feet from No. 2 quite arenaceous conditions again obtain, the sand being of a light yellowish-brown hue, and the passage into No. 4 being gradual. Owing to previous excavations only about five feet of this sand could be examined at this identical spot, but in the bottom of it could be found casts of Pectunculus decussatus - a fossil which comes up from the glauconitic bed. Nor could the junction of beds Nos. 4 and 5 anywhere be seen, owing to the similarity of hue and composition, and the way the upper part of the former had been mixed with the lower part of the latter.

The continuation of the section to the $\mathrm{N}$. and $\mathrm{E}$. showed some 30 to 40 feet of sands (No. 5), in general appearance similar to No. 4 , and for which they might easily be mistaken ; but cxamination soon revealed a somewhat unexpected condition, showing them to be light micaceous bright yellow sands, with here and there thin seams of variously-coloured pipe-clay, and in some places intercalated seams of black London clay several yards in length and three or four inches thick, frequently dipping against the slope of the hill at an angle of $3^{\circ}$ degrees. Sometimes they were very much iron-stained, and contained large quantities of angular chert (chiefly from the Lower Greensand), angular and worn ironstone and flints, white and variously-coloured quartzites, sometimes in the form of pebbles, at others of angular and subangular boulders, boulders of sandstone and limestone, and here and there a pebble of chalk. This sand thinned out over the curved faces of beds Nos. 4,3 , and 2 on to No. I, where it was followed by a most remarkable seam of pebbles from about two to four inches thick, which extended for roo yards down the hill, till it was lost below the excavations. At some parts of this seam there were extremely large blocks of Teredina-bored wood, two or three feet in length and up to thirty inches in girth, together with large pyritised fossils such as Nautili. At $\mathrm{G}$ there was a remarkable gully, about fifteen feet wide, filled with pebbles and boulders, stuck at all angles, in a chalky clay. I also excavated from it a septarium nearly two feet long, of a bright yellow and red hue: this I have no doubt was from the Kimeridge Clay, as it was entirely unlike the accompanying septaria of the London Clay, which contained Cardium, Modiola, etc.

Flanking the hill was a bed of brown London Clay (No. 6), and although a re-deposit it extended the whole length of the exposed section, so that probably much of the clay towards Holloway is not in situ Sometimes as much as $\mathrm{I}_{5}$ feet of this material was

* Quart. Joum. Geol. Soc., vol. xlvi, p. 52 (189o) 
shown, and it was this deposit that was worked for bricks. At $\mathrm{S}$ there was a large mass of black clay picked up, contorted, and spread out in the manner shown by the specimen exhibited.

By far the most extensive vertical cutting was that made in the formation of a crescent which backs towards Hornsey Lane, now laid out in unique terrace shrubberies and gardens. The crescent sweeping round into the heights on the N.E. revealed a continuous section, which may be regarded as being at right angles to section $I$, upon which its position is indicated by the dotted line. There were numerous supplementary sections exposed, but as they only repeat what is shown in these two, it is unnecessary to produce them. The excavations in section II. exposed some 3 o or 40 feet of the upper sands (No. 5), which here follow the black London Clay, from which they are separated by a curious layer, several inches thick, of crushed black flints; the sands were sifted for mortar making, and the screened material employed for road and path metal. From the paths one could easily pick up at one stooping half-a-dozen angular pieces of chert and ironstone fragments, and half as many quartzites of various colours, together with the foreign materials previously described. This cross section also revealed bed No. 6 overlying No. 5 exactly as in section I., both being overlaid by made ground, 2 or 3 feet in thickness. About a hundred yards to the right, in Hornsey Lane, in several gardens into which I got access, the uppermost bed consists of a light brown sandy clay, similar to the lower part of bed 3. At no place beyond the limits of section II. did I see the sandy bed come to the surface, so that in all probability, in the part of the section shown, bed 2 is cut away, while further to the right bed 3 comes to the surface, as the ground again begins to fall.

During the excavations Mr. Starkie Gardner visited the sections, and he immediately pointed out the impossibility of bed No. 5 being of Eocene age, as he dislodged angular pebble after pebble from the walls, and observed that whatever overlaid it must necessarily be a re-deposit. I was further assured that in the construction of Highgate railway cutting a large gulley of sand cutting into the London Clay was encountered, which was connected with the underground drainage of the locality, and into which it was necessary to throw a very large quantity of bricks. This points to some far greater erosion in the locality than we, perhaps, have previously realised.

On the highest part of the Archway on the opposite side of the road to section I., the excavations for St. Aloysius' School were dug in a sandy gravel, consisting for the most part of well rounded flint pebbles of various sizes, from very small up to two or three inches long. If this gravel contained nothing but these its claim to Bagshot might be maintained, but unfortunately in addition to these well-worn rounded pebbles, we have numerous 
others quite small and absolutely angular, quite sufficient to invalidate its claim to Eocene age.

It is, of course, a little difficult to deal with a district like this, which has been cut into to such an extent in the formation of the Archway; and it is within the realm of possibility that much of the material in making the enormous excavation under that structure might have been shot over the face of the old hill and so have added to the complexity of the sections herein described. But the exposures extended over a distance of a quarter of a mile, and an aggregate thickness of nearly one hundred feet, which reduces the probability of man's intervention to practically an impossibility, while the presence and condition of the foreign materials appear to the author wholly inexplicable upon any other hypothesis than that herein advocated. I might add that upon examination of the materials Professor Prestwich has not only no doubt of their Southern Drift origin, but considers the discovery most interesting, although not altogether surprising, but on the other hand just what might be expected.

\section{CONCLUSIONS.}

I. That in the Highgate Section we have a gradual passage from dark unctuous clay, through glauconitiferous, to ironoxide-stained sands, which in places are still in situ.

2. That these sands must be regarded as "Sands of the London Clay" and not Bagshot.

3. That the upper sands containing the constituent materials of the Southern Drift either belong to it or are a re-deposit of post-Eocene age, formed partly from the wreck of the Southern Drift.

4. That the way these sands invest the hill on the south, points either to their Northern origin or to their denudation at, or before, the deposition of the overlying clay.

5. That the "London Clay" of bed No. 6 although of considerable lateral extension, is a glacial re-deposit.

6. Granting the Southern Drift age of bed No. 5, the glacial deposits on the flanks of the hill bear the same relation to it that they bear to the Westleton Beds at Totteridge and other localities in the surrounding country. Further, a reference to Professor Prestwich's paper before quoted shows that he suspected at Highgate the existence of the Southern Drift. 


\section{List of Fossils from the London Clay.}

Membranipora eocena.

Colopleurus Wetherellii. Spines of Echinoderms.

Ditrupa plana, $S b y$.

Large crab, sp. nov. (?)

Pecten corneus.

Avicula media. papyracea, $S b y$.

Modiola simplex, $S b y$. " constricta.

Arca impolita. elegans, $S b y$.

Pectunculus decussatus.

Nucula sericea, Wood.

Cardium niteus, $S b y$.

Lucina Goodhallii, Sby.

Astarte rugosa.

Cytherea tenuistriata, $S b y$.

Tellin sp.

Tellina, 2 sps.

Syndosmya.

Solen affinis, $S b y$.

Corbula globosa.

"sp.

Teredina personata.
Rostellaria Iucida.

sp.

Murex coronatus, Sby.

Cancellaria læviuscula, Sby.

Pyrula nixilis.

Fusus trilıneatus, Sby.

$"$ regularis, $S b y$.

" complanatus, Sby.

" 3 or 4 sps.

Cassidaria nodosa, Erand.

$$
\text { " striata, } S b y \text {. }
$$

Pleurotoma teretrium, Ed. \& 2 Vars.

Metula juncea.

" Tetherellii, Ed.

", fasciolata, $E d$.

" 4 or 6 sps. (?)

Voluta nodosa.

Natica labellata, Lam.

Sigareta, sp.

Diastoma, sp. (?)

Melania, sp. (?)

Phorus agglutinans.

Ringicula turgida.

Bulla, sp.

Otodus.

Lamna.

Various otoliths.

Highgate resin.

Websterite.

\section{Explanation of the Figure.}

Section I. is parallel to the Highgate Archway Road : length of section about $\frac{1}{4}$ mile.

Section II. is at right angles to Section I. (starting from it at the point indicated by the dotted line), and backing against Hornsey Lane.

6. Re-deposited London Clay.

5. Bright brownish-yellow sand with erratics.

4. " " " sand.

3. " " " sandy clay.

2. Highly fossiliferous" glauconitic sand

I. Unctuous shocolate-brown London Clay.

G. Gully with boulders in chalky clay.

S. Large mass of picked-up London Clay. 


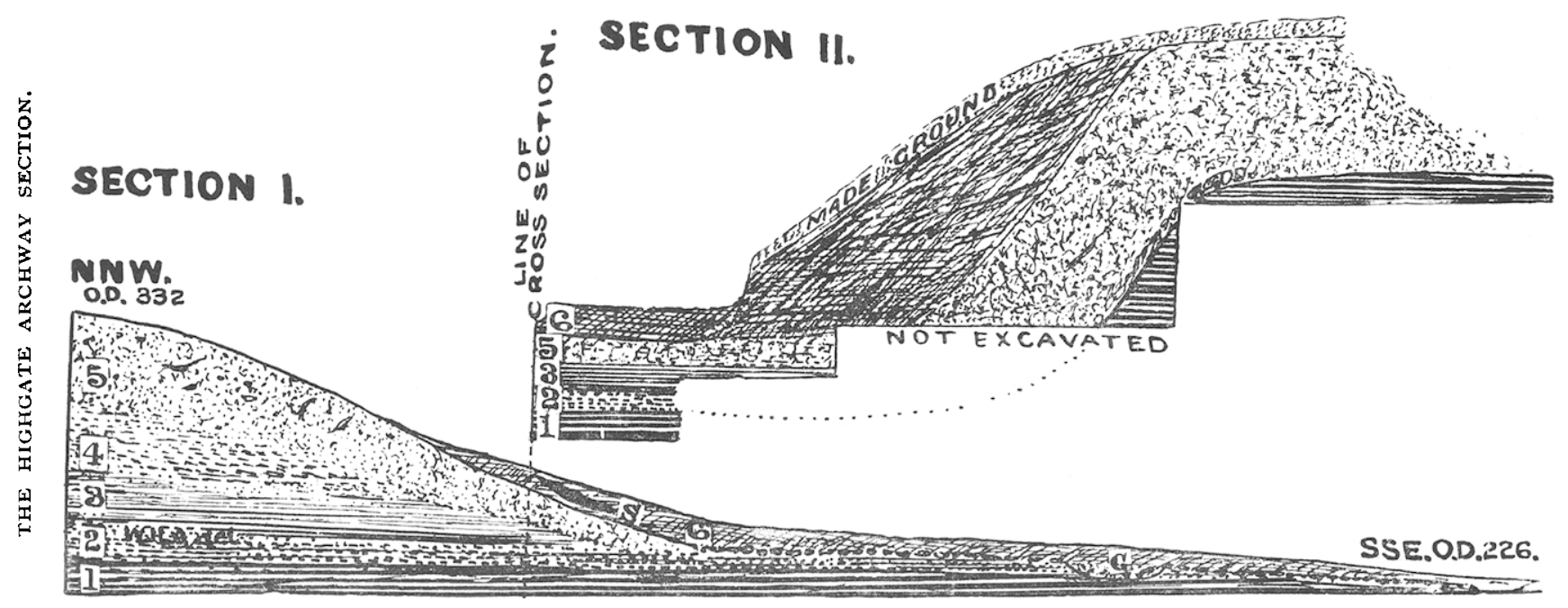


Fig. ia.-Profite of the Country South of Dublin, from Bray Head to the Great Sugar Loaf, looking southwards.(After Weaver.)

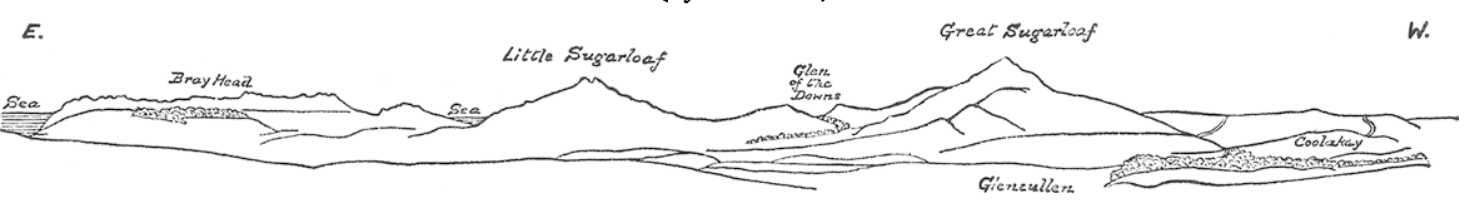

Fig, ib.--Profile of the Country abound Dublin, from Glencullen to Lambay, looking northwards.-(After Weaver)

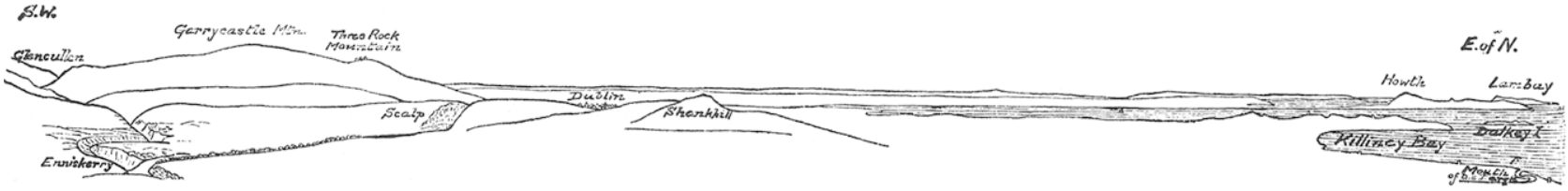

